\title{
SYNTHESIS OF NOVEL 1,2-DIOL CONTAINING AZO DYES FOR POLYMERIC SUBSTRATES
}

\author{
HAMDULLAH KHADIM SHEIKH*, MEHDI HASSAN KAZMI
}

Department of Applied Chemistry \& Chemical technology, University of Karachi. KU Circular Road, Karachi 75270, Pakistan.

\section{ABSTRACT}

Two novel 1,2-diol containing azo dyes have been synthesized for application on polymeric textile substrates. We used multistep synthesis scheme which involved selectively bonding azo chromophore with glycerol moiety such that only one alcohol out of the three gets bonded to the chromophore while rest two remain unchanged. The 1,2-diol moiety, common in both dyes, is responsible for forming hydrogen bonds with polar sites on a polymeric substrate. The molecular structure of the final molecule and synthesized intermediates were elucidated by UV/Vis, FT-IR, MS (EI, ESI, and CI) and ${ }^{1} \mathrm{H}-\mathrm{NMR}$ spectroscopic techniques. Dyes were applied to polyester and nylon 66 fabrics as disperse dyes by exhaust dyeing method and furnished good to excellent fastness properties on both of them.

Keywords: Azo chromophore, Glycerol, Hydrogen bond, Polyester, Nylon 66

\section{INTRODUCTION}

Other than ionic or covalent bonding, hydrogen bonding along with dipoledipole interaction and dispersion forces are the major modes of intermolecular interaction between dye molecule and substrates specifically in textile synthetic fiber dyeing ${ }^{1,2}$. Recently, there has been a lot of interest in synthesis of new disperse dyes ${ }^{3,4,5,6}$. Almost all these newly developed dyes are small planar molecules that can easily penetrate in between the polymeric chains of fiber. Usually, they contain protic or aprotic polar groups that are capable of forming hydrogen bonds with polar sites (mostly hydrogen bond acceptor groups) of the polymeric substrates. Higher number of polar sites in the dye molecule results in more dyeing affinity and better fastness properties because of intermolecular interaction between these sites within fiber and dye molecule ${ }^{7}$. Our work is aimed at exploring the potential utility of polyhydric alcohols in combination with azo chromophore to form a disperse dye with superior dyefiber interaction capacity. The designed glycerol azo dyes $\mathbf{E}$ and $\mathbf{F}$ are small and planar molecules that can easily enter the space between polymeric chains of the substrate while on the edge of the molecule they wield two vicinal $\mathrm{OH}$ sites that are capable of interacting with polar sites on the substrate (Figure 1). This results in better fixation and fastness properties. Selection of polyhydric alcohols was based upon that fact that $\mathrm{OH}$ group forms stronger hydrogen bonds compared to other protic moieties like amines because of larger electronegativity difference between $\mathrm{O}$ and $\mathrm{H}^{8}$.

Synthesis route (Scheme 1) involved bonding the partially protected form of glycerol A with 4-(dimethylamino)benzoic acid to form C (Couplar I). For the synthesis of $\mathbf{F}, \mathbf{C}$ was directly coupled with diazonium compound. For the synthesis of $\mathbf{E}, \mathbf{C}$ was deprotected in acidic conditions to reform the diol moiety. The resultant molecule D (Couplar II) served as a coupling component that coupled with a diazonium compound to form azo chromophore E. D (Couplar II) with its two vicinal OH groups, provides the opportunity to further modify the structure of coupling component before chromophore formation.

We selected azo chromophore to play the role of color imparting part in our intended molecule. Azo dyes represent by far the most significant class of commercial organic dyes. They account for $60-70 \%$ of the dye used in traditional textile application 9 . Azo chromophore synthesis also provides the margin to tune up the intended molecular properties as per requirement.

\section{EXPERIMENTAL}

\section{Materials:}

All the reagents and solvents were obtained from Merck Millipore and Sigma-Aldrich Chemical Company, USA. All the solvents were of analytical grade and were dried using standard methods. Melting points were recorded on Griffin MFB-590 melting point apparatus and are uncorrected. IR spectra were registered on Jasco-320-A spectrophotometer using $\mathrm{KBr}$ discs. UVVis spectra were recorded on Thermoscientific evolution-300 UV-Vis spectrophotometer. ${ }^{1} \mathrm{H}-\mathrm{NMR}$ spectra were recorded in $\mathrm{CDCl}_{3}$ with $\mathrm{SiMe}_{4}$ as the internal standard at 300, 400 and $500 \mathrm{MHz}$ on different types of Bruker Avance AM spectrometers. ESI-MS were recorded on QSTAR XL Hybrid LC/MS/MS mass spectrometer. EI-MS was recorded on Varian MAT 312 spectrometer. CI-MS was recorded on JOEL JM S-600H mass spectrometer. All reactions and purity were monitored by thin layer chromatography (TLC), performed on Merck pre-coated silica gel $60 \mathrm{~F}_{254} 20 \times 20 \mathrm{~cm}$ aluminum sheets and spots seen under UV light at 254 and $366 \mathrm{~nm}$. Dyeing was carried out on Roaches Model-S multi bath dyeing machine. Imerol X nonionic detergent, Laval RDN dispersing agent, PES and nylon 66 fabrics were acquired from Archroma Pakistan limited.

\section{Synthesis:}

\section{(2,2-Dimethyl-1,3-dioxolan-4-yl)methanol (A):}

Glycerol $(0.246 \mathrm{~mol})$ and acetone $(0.738 \mathrm{~mol})$ were heated to reflux in the presence of p-toluenesulfonic acid $(0.68 \mathrm{gm})$ for 10 hours. Reaction vessel was then brought to room temperature and cold $\mathrm{Na}_{2} \mathrm{CO}_{3}$ solution $(0.035 \mathrm{M})$ was added to it. Organic product layer was extracted with dichloromethane (DCM), dried over sodium sulfate. Evaporation of the solvent gave the pure 1, 2 isopropylidene glycerol (solketal) A.

Colorless liquid; yield: $71 \%$; b.p. $189{ }^{\circ} \mathrm{C}$; UV-Vis $(13.5 \mathrm{M}$ in Ethyl acetate) $\left[\lambda_{n}, \mathrm{~nm}\left(\varepsilon_{,}, \mathrm{L} \mathrm{mol}^{-1} \mathrm{~cm}^{-1}\right)\right] 271.0(0.29) ; \mathrm{IR}(\mathrm{KBr}) v_{\mathrm{max}}\left(\mathrm{cm}^{-1}\right): 3416.7$ (O-H alcohol), 2935.5 (C-H aliphatic), 1120.0 (C-O ether), 1051.1 (C-O $1^{\circ}$ alcohol); ${ }^{1} \mathrm{H}-\mathrm{NMR}\left(\mathrm{CDCl}_{3} 300 \mathrm{MHz}, 25^{\circ} \mathrm{C}, \mathrm{TMS}\right) \delta(\mathrm{ppm}): 1.33\left(3 \mathrm{H}, \mathrm{s}, \mathrm{C}_{1} H_{3}\right)$, $1.40\left(3 \mathrm{H}, \mathrm{s}, \mathrm{C}_{2} \mathrm{H}_{3}\right), 3.58\left(1 \mathrm{H}, \mathrm{m},-\mathrm{C}_{4} \mathrm{H}_{2}-\mathrm{O}-\right), 3.67\left(1 \mathrm{H}, \mathrm{m},-\mathrm{C}_{4} \mathrm{H}_{2}-\mathrm{O}-\right), 3.77(1 \mathrm{H}$, m, - $\left.\mathrm{C}_{6} \mathrm{H}_{2}-\mathrm{O}-\right), 4.02\left(1 \mathrm{H}, \mathrm{m},-\mathrm{C}_{6} \mathrm{H}_{2}-\mathrm{O}-\right)^{2}, 4.21$ (1H,m, - $\left.\mathrm{C}_{5} \mathrm{H}-\mathrm{O}-\right)$; EI-MS $m / z$ (rel. int.): $132[\mathrm{M}]^{+}(1.02), 117(28.68)\left[\mathrm{M}_{-} \mathrm{CH}_{3}\right]^{+}, 101(50.29)\left[\mathrm{M}-\mathrm{CH}_{3} \mathrm{O}\right]^{+}, 73$ (42.13) $\left[\mathrm{M}-\mathrm{C}_{3} \mathrm{H}_{7} \mathrm{O}\right]^{+}, 57(100)\left[\mathrm{M}-\mathrm{C}_{3} \mathrm{H}_{7} 2 \mathrm{O}\right]^{+}$.

\section{(2,2-Dimethyl-1,3-dioxolan-4-yl)methyl 4-(dimethylamino)benzoate (C):}

4-(dimethylamino)benzoic acid $\left(5 \times 10^{-3} \mathrm{~mol}\right)$ and carbonyldiimidazole $(5$ x $\left.10^{-3} \mathrm{~mol}\right)$ were dissolved in THF $(30 \mathrm{ml})$. After 2 hours of stirring, solketal A $(0.0125 \mathrm{~mol})$ was added into the vessel along with triethylamine base $(0.52$ $\mathrm{ml})$. Reaction mixture was left stirring for 48 hours after which solvent was dried off. Solid reaction mixture was poured into $0.05 \mathrm{M}$ solution of $\mathrm{Na}_{2} \mathrm{CO}_{3}$. The obtained precipitate of the product was filtered, washed again with water, extracted with dichloromethane and was dried over sodium sulfate. Evaporation of solvent gave the ester product $\mathbf{C}$.

White solid; yield: $40 \%$; m.p. $89^{\circ} \mathrm{C}$; UV-Vis $\left(3.58 \times 10^{-5} \mathrm{M}\right.$ in Ethyl acetate) $\left[\lambda_{\max }, \mathrm{nm}\left(\varepsilon_{\max }, \mathrm{L} \mathrm{mol}{ }^{-1} \mathrm{~cm}^{-1}\right)\right] 310.0$ (57725.1); IR $(\mathrm{KBr}) v_{\max }\left(\mathrm{cm}^{-}\right.$ $\left.{ }^{1}\right): 2934.53$ (C-H aliphatic), $1692.74(\mathrm{C}=\mathrm{O}$ ester), $1614.41(\mathrm{C}=\mathrm{C}$ aromatic), 1277.52 (C-O ester), 1205.94 (C-N amine), 1105.42 (C-O ether) $\mathrm{cm}^{-1} ;{ }^{1} \mathrm{H}-\mathrm{NMR}$ $\left(\mathrm{CDCl}_{3} 400 \mathrm{MHz}, 25^{\circ} \mathrm{C}, \mathrm{TMS}\right) \delta(\mathrm{ppm}): 1.37\left(3 \mathrm{H}, \mathrm{s}, \mathrm{C}_{1} H_{3}\right), 1.43\left(3 \mathrm{H}, \mathrm{s}, \mathrm{C}_{2} H_{3}\right)$, $3.04\left(6 \mathrm{H}, \mathrm{s}, \mathrm{C}_{14} H_{3}, \mathrm{C}_{15} \mathrm{H}_{3}\right), 3.86\left(1 \mathrm{H}, \mathrm{m},-\mathrm{C}_{4} \mathrm{H}_{2}-\mathrm{O}-\right), 4.13\left(1 \mathrm{H}, \mathrm{m},-\mathrm{C}_{4} \mathrm{H}_{2}-\mathrm{O}-\right)$ $4.34\left(2 \mathrm{H}, \mathrm{m},-\mathrm{C}_{6} H_{2}-\mathrm{O}\right), 4.43\left(1 \mathrm{H}, \mathrm{m},-\mathrm{C}_{5} H-\mathrm{O}-\right), 6.84\left(2 \mathrm{H}, \mathrm{d}, J=8.8 \mathrm{~Hz}, \mathrm{C}_{10} H\right.$, $\left.\mathrm{C}_{12} H\right), 7.96\left(2 \mathrm{H}, \mathrm{d}, J=8.8 \mathrm{~Hz}, \mathrm{C}_{9} H, \mathrm{C}_{13} H\right) ;(+)$ ESI-MS $\left.m / z: 280.1[\mathrm{M}+\mathrm{H}]^{+}\right)$, $222.1\left[\mathrm{M}-\mathrm{C}_{3} \mathrm{H}_{5} \mathrm{O}_{4}\right]^{+}, 148.1\left[\mathrm{M}-\mathrm{C}_{3} \mathrm{H}_{11} \mathrm{O}_{3}\right]^{+}, 122.6\left[\mathrm{M}-\mathrm{C}_{7} \mathrm{H}_{9} \mathrm{O}_{4}\right]^{+}$.

2,3-Dihydroxypropyl 4-(dimethylamino)benzoate (D): 
Product $\mathbf{C}\left(3 \times 10^{-3} \mathrm{~mol}\right)$ and boric acid $(0.032 \mathrm{~mol})$ is dissolved in the 25 $\mathrm{ml}$ of diglyme and $\mathrm{H}_{2} \mathrm{O}$ mixture $(4: 1)$. Temperature was raised to $100{ }^{\circ} \mathrm{C}$ and reaction is continued for 3.5 hours. The reaction mass is then cooled down to room temperature and solvent is evaporated under vacuum. Solid product mass is dissolved in water and extracted with dichloromethane. Dissolved product is dried over sodium sulfate. Evaporation of dichloromethane gave the deprotected product $\mathbf{D}$.

White solid; yield: $95 \%$; m.p. $90{ }^{\circ} \mathrm{C}$; UV-Vis $\left(4.18 \times 10^{-5} \mathrm{M}\right.$ in Ethyl acetate) $\left[\lambda, \mathrm{nm}\left(\varepsilon_{\mathrm{m}}, \mathrm{L} \mathrm{mol}{ }^{-1} \mathrm{~cm}^{-1}\right)\right] 310.0$ (49450.2); IR $(\mathrm{KBr}) v\left(\mathrm{~cm}^{-1}\right)$ : 3459.0 (O-H alcohol), 2934.0 (C-H aliphatic), 1693.0 (C=O ester), 1611.81 $(\mathrm{C}=\mathrm{C}$ aromatic), 1277.52 (C-O ester), 1206.17 (C-N amine), 1038.32 (C-O $1^{\circ}$ alcohol), 1105.06 (C-O $2^{\circ}$ alcohol); ${ }^{1} \mathrm{H}-\mathrm{NMR}\left(\mathrm{CDCl}_{3} 400 \mathrm{MHz}, 25{ }^{\circ} \mathrm{C}\right.$, TMS) $\delta(\mathrm{ppm}): 3.05\left(6 \mathrm{H}, \mathrm{s}, \mathrm{C}_{11} H_{3}, \mathrm{C}_{12} H_{3}\right), 3.86\left(1 \mathrm{H}, \mathrm{m}, \mathrm{C}_{1} H_{2}-\mathrm{O}-\right), 4.13(1 \mathrm{H}$, m, $\left.\mathrm{C}_{1} H_{2}-\mathrm{O}-\right), 4.34\left(2 \mathrm{H}, \mathrm{m}, \mathrm{C}_{3} H_{2}-\mathrm{O}-\right), 4.43\left(1 \mathrm{H}, \mathrm{m}, \mathrm{C}_{2} H-\mathrm{O}-\right), 6.92(2 \mathrm{H}, \mathrm{d}, J=$ $\left.8.4 \mathrm{~Hz}, \mathrm{C}_{7} H \mathrm{C}_{9} H\right), 7.98\left(2 \mathrm{H}, \mathrm{d}, J=8.8 \mathrm{~Hz}, \mathrm{C}_{6} H \mathrm{C}_{10} H\right)$; (+)ESI-MS $m / z: 240.1$ $[\mathrm{M}+\mathrm{H}]^{+}, 207.1\left[\mathrm{M}-\mathrm{CH}_{4} \mathrm{O}\right]^{+}, 166\left[\mathrm{M}-\mathrm{C}_{3} \mathrm{H}_{5} 2 \mathrm{O}\right]^{+}, 148\left[\mathrm{M}-\mathrm{C}_{3} \mathrm{H}_{7} \mathrm{O}_{3}\right]^{+}$ (E):

2,3-Dihydroxypropyl 4-(dimethylamino)-3-(4-nitrophenyl)azo]benzoate

Nitroaniline $\left(2.85 \times 10^{-3} \mathrm{~mol}\right)$ was taken in a beaker along with $5.7 \times 10^{-}$ ${ }^{3} \mathrm{~mol}$ of $\mathrm{HCl}$. Mixture was cooled to $0{ }^{\circ} \mathrm{C}$. In another vessel sodium nitrite $\left(2.85 \times 10^{-3} \mathrm{~mol}\right)$ was dissolved in $10 \mathrm{ml}$ of water and cooled to $0{ }^{\circ} \mathrm{C}$. Sodium nitrite solution was slowly added dropwise to the nitroaniline and $\mathrm{HCl}$ vessel. In another vessel, $2.85 \times 10^{-3} \mathrm{~mol}$ of $\mathbf{D}$ was dissolved in $100 \mathrm{ml}$ ethanol and brought to $0{ }^{\circ} \mathrm{C}$. Diazonium solution of nitroaniline was slowly added to the vessel containing $\mathbf{D}$ while maintaining the $\mathrm{pH}$ at 5.5 with $2 \%$ sodium acetate solution. Reaction mixture is stirred at constant conditions for 2.5 hours after which azo compound starts to precipitate out, which is filtered. Solid product mass is then dissolved in water and extracted with dichloromethane, dried over sodium sulfate. Evaporation of dichloromethane gave the azo product $\mathbf{E}$.

Bright red powder; yield: $76 \%$; m.p. $135^{\circ} \mathrm{C}$; Rf: 0.56 (Ethyl acetate:Hexane, 1:9); UV-Vis $\left(5.15 \times 10^{-5} \mathrm{M}\right.$ in DMF) $\left[\lambda, \mathrm{nm}\left(\varepsilon, \mathrm{L} \mathrm{mol}^{-1} \mathrm{~cm}^{-1}\right)\right] 494.0$ (60194.1); IR (KBr) $v_{\max }\left(\mathrm{cm}^{-1}\right): 3442.7$ (O-H alcohol), 2923.9 (C-H aliphatic), $1697.2(\mathrm{C}=\mathrm{O}$ ester), $1608.5(\mathrm{C}=\mathrm{C}$ aromatic $), 1514.0(\mathrm{~N}=\mathrm{N}$ azo $), 1371.3(\mathrm{~N}-\mathrm{O}$ nitro), 1278.7 (C-O ester), 1118.1 (C-N amine), 1039.6 (C-O $1^{\circ}$ alcohol), 1105.1 (C-O $2^{\circ}$ alcohol); ${ }^{1} \mathrm{H}-\mathrm{NMR}\left(\mathrm{CDCl}_{3} 400 \mathrm{MHz}, 25^{\circ} \mathrm{C}\right.$, TMS) $\delta$ (ppm): $3.03\left(6 \mathrm{H}, \mathrm{s}, \mathrm{C}_{11} H_{3}, \mathrm{C}_{12} H_{3}\right), 3.86\left(1 \mathrm{H}, \mathrm{m}, \mathrm{C}_{1} H_{2}-\mathrm{O}-\right), 4.13\left(1 \mathrm{H}, \mathrm{m},-\mathrm{C}_{1} H_{2}-\mathrm{O}-\right), 4.34$ $\left(2 \mathrm{H}, \mathrm{m}, \mathrm{C}_{3} H_{2}-\mathrm{O}-\right), 4.43\left(1 \mathrm{H}, \mathrm{m}, \mathrm{C}_{2} H-\mathrm{O}-\right), 6.86\left(1 \mathrm{H}, \mathrm{d}, J=8.4 \mathrm{~Hz}, \mathrm{C}_{7} H\right), 7.54$ $\left(2 \mathrm{H}, \mathrm{d}, J=8.8 \mathrm{~Hz}, \mathrm{C}_{14} H, \mathrm{C}_{18} H\right), 7.69\left(1 \mathrm{H}, \mathrm{d}, J=8.8 \mathrm{~Hz}, \mathrm{C}_{6} H\right), 7.93(2 \mathrm{H}, \mathrm{d}, J=$ $\left.8.8 \mathrm{~Hz}, \mathrm{C}_{15} H, \mathrm{C}_{7} H\right), 8.01\left(1 \mathrm{H}, \mathrm{s}, \mathrm{C}_{10} H\right) ;(-) \mathrm{CI}-\mathrm{MS} m / z: 387.1[\mathrm{M}-\mathrm{H}]$ ] 371.1 $[\mathrm{M}-\mathrm{OH}]^{-}, 266.1\left[\mathrm{M}-\mathrm{C}_{6} \mathrm{H}_{4} \mathrm{NO}_{2}\right]$; Anal. Calc. for $\mathrm{C}_{18} \mathrm{H}_{20} \mathrm{~N}_{4} \mathrm{O}_{6}: \mathrm{C}, 55.67 ; \mathrm{H}, 5.19$ N, 14.43; O, $24.72 \%$. Found: 55.64; H, 5.18; N, 14.45; O, $24.70 \%$. (F)

2,3-Dihydroxypropyl 3-[(4-acetylphenyl)azo]-4-(dimethylamino)benzoate

Sodium nitrite $\left(2.85 \times 10^{-3} \mathrm{~mol}\right)$ was dissolved in $10 \mathrm{ml}$ of water and cooled to $0{ }^{\circ} \mathrm{C}$. In a separate pre-chilled beaker at $0{ }^{\circ} \mathrm{C}$, 4-aminoacetophenone $(2.85$ $\left.\mathrm{x} 10^{-3} \mathrm{~mol}\right)$ was taken along with $\mathrm{HCl}\left(5.7 \times 10^{-3} \mathrm{~mol}\right)$. Sodium nitrite solution was slowly added dropwise to the nitroaniline and $\mathrm{HCl}$ vessel. In another vessel, $\mathbf{C}\left(2.85 \times 10^{-3} \mathrm{~mol}\right)$ was stirred in $100 \mathrm{ml}$ ethanol and cooled to $0{ }^{\circ} \mathrm{C}$. Diazonium solution of 4-aminoacetophenone was slowly added to the vessel containing coupling component $\mathbf{C}$ while maintaining $\mathrm{pH}$ with $2 \%$ sodium acetate solution. Reaction mixture is stirred at constant conditions for 4 hours after which azo compound starts to precipitate out, which is filtered. Solid product mass is then dissolved in water and extracted with dichloromethane, dried over sodium sulfate. Evaporation of solvent gave the azo product $\mathbf{F}$ which was further purified by column chromatography (ethyl acetate: hexane).

Rust colored powder; yield: $65 \%$; m.p. $130{ }^{\circ} \mathrm{C}$; Rf: 0.40 (Ethyl acetate:Hexane, 1:9); UV-Vis (7.27 x 10-5 M in DMF) $\left[\lambda_{\max }, \mathrm{nm}\left(\varepsilon_{\max }, \mathrm{L} \mathrm{mol}^{-1}\right.\right.$ $\left.\mathrm{cm}^{-1}\right)$ ]: 415.0 (41265.4); IR (KBr) $v_{\text {max }}\left(\mathrm{cm}^{-1}\right)$ : 3442.7 (O-H alcohol), 2923.9 (C-H aliphatic), $1693.4(\mathrm{C}=\mathrm{O}$ ester), $1680.0(\mathrm{C}=\mathrm{O}$ ketone $), 1608.5(\mathrm{C}=\mathrm{C})$, $1519.8\left(\mathrm{~N}=\mathrm{N}\right.$ azo), 1274.9 (C-O ester), 1188.1 (C-N amine), 1043.4 (C-O ${ }^{\circ}$ alcohol), 1105.1 (C-O $2^{\circ}$ alcohol); ${ }^{1} \mathrm{H}-\mathrm{NMR}\left(\mathrm{CDCl}_{3} 500 \mathrm{MHz}, 25{ }^{\circ} \mathrm{C}, \mathrm{TMS}\right) \delta$ (ppm): $2.59\left(3 \mathrm{H}, \mathrm{s}, \mathrm{C}_{20} H_{3}\right), 3.05\left(6 \mathrm{H}, \mathrm{s}, \mathrm{C}_{11} \mathrm{H}_{3}, \mathrm{C}_{12} H_{3}\right), 3.86\left(1 \mathrm{H}, \mathrm{m}, \mathrm{C}_{1} \mathrm{H}_{2}-\mathrm{O}-\right)$, $4.13\left(1 \mathrm{H}, \mathrm{m}, \mathrm{C}_{1} \mathrm{H}_{2}-\mathrm{O}-\right), 4.34\left(2 \mathrm{H}, \mathrm{m}, \mathrm{C}_{3} \mathrm{H}_{2}-\mathrm{O}-\right), 4.44\left(1 \mathrm{H}, \mathrm{m}, \mathrm{C}_{2} \mathrm{H}-\mathrm{O}-\right)^{2}, 7.49$ $\left(1 \mathrm{H}, \mathrm{d}, J=8.5 \mathrm{~Hz}, \mathrm{C}_{7} H\right), 7.97\left(2 \mathrm{H}, \mathrm{d}, J=8.0 \mathrm{~Hz}, \mathrm{C}_{14} H, \mathrm{C}_{18} H\right), 7.89(1 \mathrm{H}, \mathrm{d}, J=$ $\left.9.0 \mathrm{~Hz}, \mathrm{C}_{6} H\right), 8.01\left(2 \mathrm{H}, \mathrm{d}, J=8.5 \mathrm{~Hz}, \mathrm{C}_{15} H, \mathrm{C}_{17} H\right), 8.02\left(1 \mathrm{H}, \mathrm{s}, \mathrm{C}_{10} H\right)$ ) $)$; (-)CIMS $m / z: 384.1[\mathrm{M}-\mathrm{H}]^{-}, 324.1$ [M-C H O ]; 266.1 [M-C $\mathrm{H}_{8} \mathrm{O}$ ]; Anal. Calc. for $\mathrm{C}_{20} \mathrm{H}_{23} \mathrm{~N}_{3} \mathrm{O}_{5}: \mathrm{C}, 62.33 ; \mathrm{H}, 6.01 ; \mathrm{N}, 10.90 ; \mathrm{O}, 20.76 \%$. Found: $\mathrm{C}, 62.34 ; \mathrm{H}, 6.00$; $\mathrm{N}, 10.88 ; \mathrm{O}, 20.77 \%$

\section{Dyeing process:}

Same dyeing procedure was used for both dyes $\mathbf{E}$ and $\mathbf{F}$ on polyester and nylon fabrics separately with $1 \%, 2 \%$ and $3 \%$ dye o.w.f (on weight of fabric). Fabric (10 gm) was first prewashed in the liquor ratio of 1:20 with a nonionic detergent imerol X $(2 \mathrm{~g} / \mathrm{L})$ in presence of sodium carbonate $(2 \mathrm{~g} / \mathrm{L})$ at $70{ }^{\circ} \mathrm{C}$ for 30 mins. Fabric was then allowed to dry.

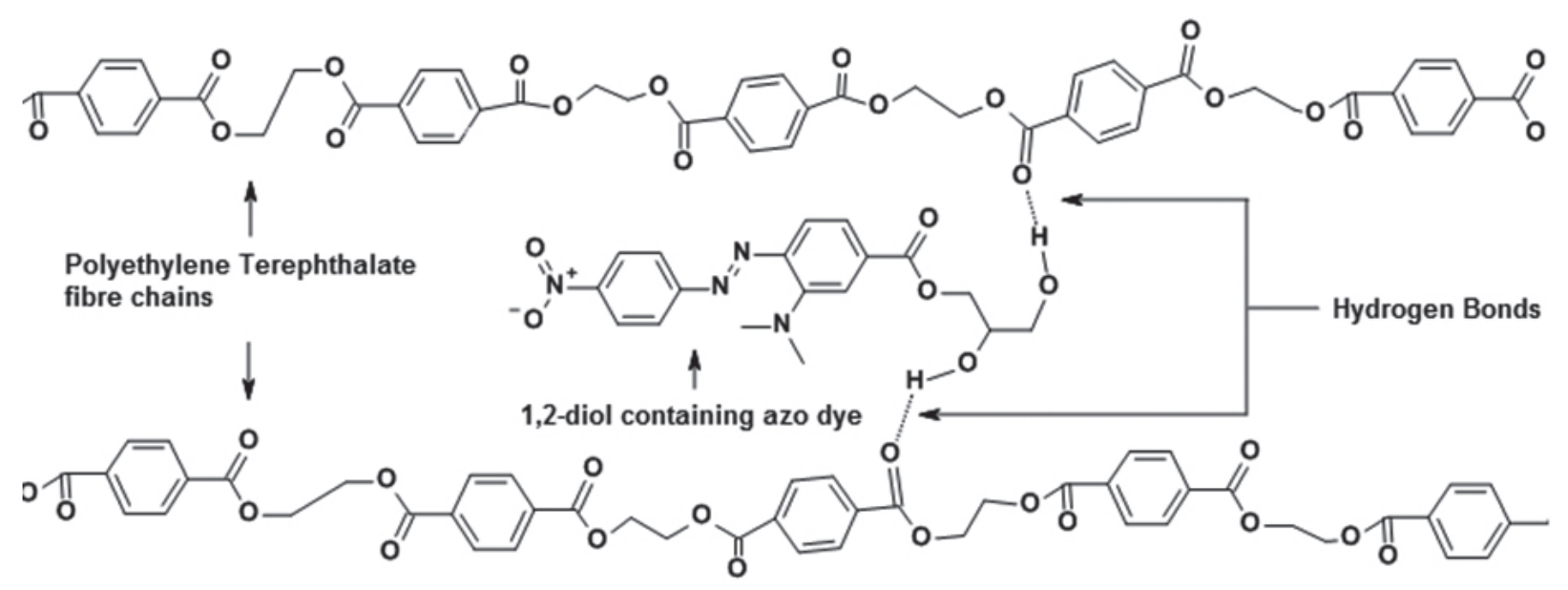

Figure 1.- 1,2- Diol moiety of dye molecule forming hydrogen bonds with adjacent polyester chains.

$10 \mathrm{gm}$ of prewashed fabric was immersed in an aqueous bath maintained at $60{ }^{\circ} \mathrm{C}$ with a liquor ratio of $1: 20$. $\mathrm{pH}$ at 5.5 was adjusted by acetic acid (10\%). $2 \mathrm{~g} / \mathrm{L}$ of dispersing agent lycol RDN was added to the bath. The sample was allowed to run for about $15 \mathrm{mins}$ then $0.5 \mathrm{~g} / \mathrm{L}$ ( $1 \%$ dye o.w.f) dye was added to the liquor. Temperature was increased from 60 to $100{ }^{\circ} \mathrm{C}$ at the rate of $2{ }^{\circ} \mathrm{C} /$ min followed by further elevation from $100{ }^{\circ} \mathrm{C}$ to $120^{\circ} \mathrm{C}$ at $1{ }^{\circ} \mathrm{C} / \mathrm{min}$. Dyeing was allowed to carry on for 60 mins. Dyeing vessel was then cooled back to 75 ${ }^{\circ} \mathrm{C}$ at $3{ }^{\circ} \mathrm{C} / \mathrm{min}$. Sample was rinsed with cold water multiple times and divided into pieces for fastness evaluation tests. Process was repeated for $2 \%$ and $3 \%$ dye concentrations for both PES and nylon fabrics. Dyeing process is given in Figure 2. 


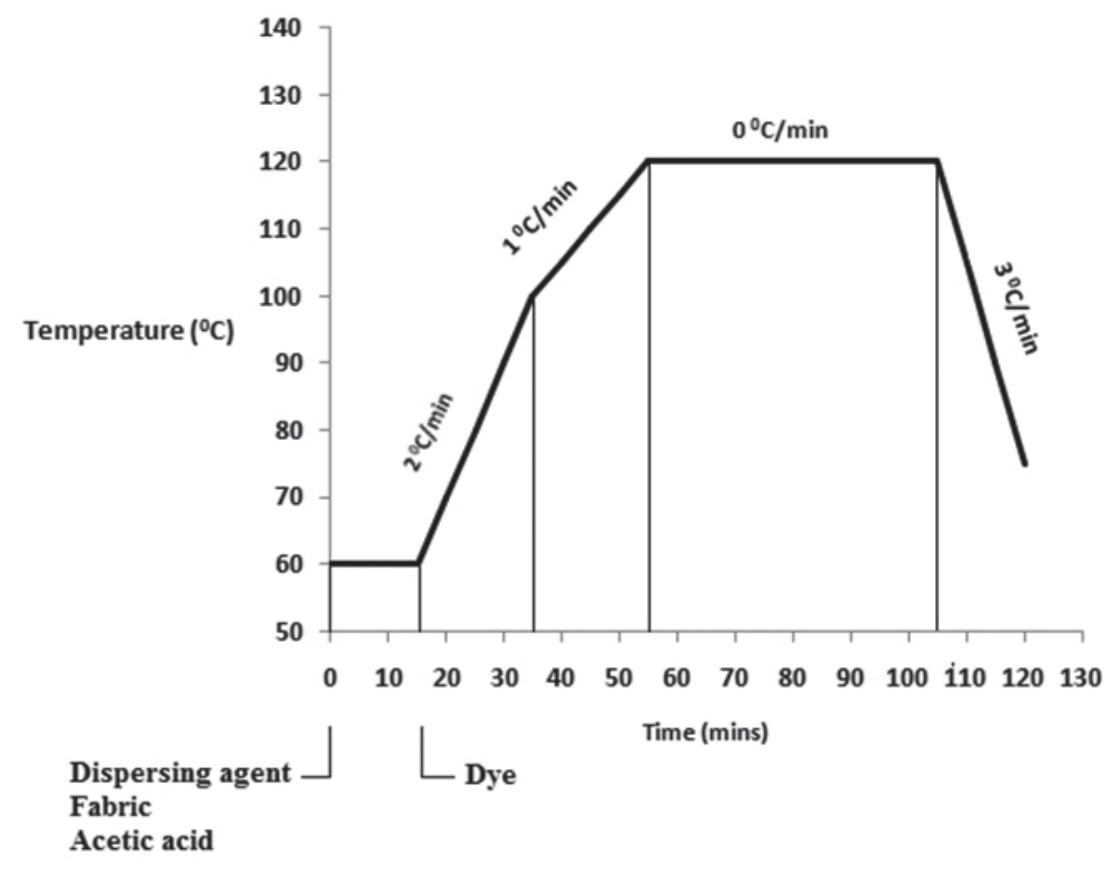

Figure 2.- Dyeing process.

Color Fastness tests:

Dye's fastness to light, sublimation, washing, rubbing and perspiration were evaluated in accordance with ISO standards ISO 105-B02,ISO 105-P01, ISO 105- C01-4, ISO 105-X12 and ISO105-E04 respectively. Grey scale was used for assessing the change in shades while blue scale was used for evaluation of light fastness test result. The details of these tests are reported in literature ${ }^{10}$. Table 1 shows the obtained fastness results.

Table 1. Fastness evaluation.

\begin{tabular}{|c|c|c|c|c|c|c|c|c|c|c|c|c|}
\hline \multirow{3}{*}{ Test } & \multicolumn{4}{|c|}{$1 \%$ Dye o.w.f } & \multicolumn{4}{|c|}{$2 \%$ Dye o.w.f } & \multicolumn{4}{|c|}{$3 \%$ Dye o.w.f } \\
\hline & \multicolumn{2}{|c|}{ Dye E } & \multicolumn{2}{|c|}{ Dye F } & \multicolumn{2}{|c|}{ Dye E } & \multicolumn{2}{|c|}{ Dye F } & \multicolumn{2}{|c|}{ Dye $E$} & \multicolumn{2}{|c|}{ Dye F } \\
\hline & PES & $\begin{array}{c}\text { Nylon } \\
66\end{array}$ & PES & Nylon 66 & PES & $\begin{array}{c}\text { Nylon } \\
66\end{array}$ & PES & $\begin{array}{c}\text { Nylon } \\
66\end{array}$ & PES & $\begin{array}{c}\text { Nylon } \\
66\end{array}$ & PES & Nylon 66 \\
\hline Light & 5 & 5 & $4-5$ & $4-5$ & 5 & 5 & $4-5$ & 4 & 5 & 5 & $4-5$ & 4 \\
\hline \multicolumn{13}{|l|}{ Washing a } \\
\hline$A$ & 5 & $4-5$ & 5 & $4-5$ & 5 & 5 & $4-5$ & $4-5$ & 5 & 5 & $4-5$ & $4-5$ \\
\hline$B$ & 5 & 5 & 5 & $4-5$ & 5 & 5 & $4-5$ & $4-5$ & 5 & 5 & $4-5$ & $4-5$ \\
\hline$C$ & 4 & 4 & $4-5$ & 4 & 4 & 4 & $4-5$ & 4 & 4 & 4 & $4-5$ & 4 \\
\hline$D$ & 4 & 4 & 4 & 4 & 4 & 4 & 4 & 4 & 4 & 4 & $3-4$ & 4 \\
\hline \multicolumn{13}{|l|}{ Perspiration } \\
\hline Acid & 5 & 5 & 5 & $4-5$ & 5 & 5 & 5 & $4-5$ & 5 & 5 & 5 & $4-5$ \\
\hline Alkaline & 5 & 5 & 5 & 5 & 5 & 5 & 5 & 5 & 5 & 5 & 5 & $4-5$ \\
\hline \multicolumn{13}{|l|}{ Rubbing } \\
\hline Dry & 5 & 5 & 5 & 5 & 5 & 5 & 5 & 5 & 5 & 5 & 5 & 5 \\
\hline Wet & 4 & 4 & 4 & 4 & 4 & 4 & 4 & 4 & 4 & 4 & 4 & 4 \\
\hline Sublimation & 4 & 4 & $4-5$ & $4-5$ & 4 & 4 & $4-5$ & 5 & 4 & 4 & 4 & $4-5$ \\
\hline
\end{tabular}

${ }^{\mathrm{a}} A=I S O-105-C 01, B=I S O-105-C 02, C=I S O-105-C 03, D=I S O-105-C 04$

\section{RESULTS AND DISCUSSION}

We first partially protected the glycerol's $\mathrm{OH}$ groups in such a way that two of them get protected (1,2-isopropylidene glycerol or solketal A) and one remains available for further reaction. Physical and spectral data showed complete agreement to that reported in literature ${ }^{11}$. 2nd step involved esterification of an activated arene (aromatic ring with electron donating substituent) with 1,2-isopropylidene glycerol $\mathbf{A}$. The activated arene itself must have suitable electrophilic substituent group on it that can bond with the lone $1^{0} \mathrm{OH}$ of 1,2-isopropylidene glycerol $\mathbf{A}$. We chose 4-(dimethylamino)benzoic acid as shown in Figure 3. Selection of $\mathrm{N}\left(\mathrm{CH}_{3}\right)_{2}$ substituent on aromatic ring was based upon the fact that we needed an electron 


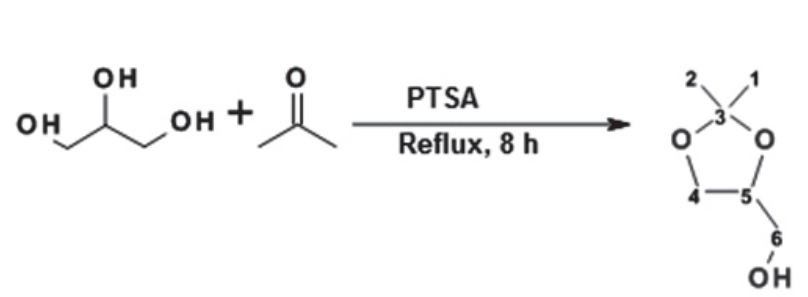

(A)

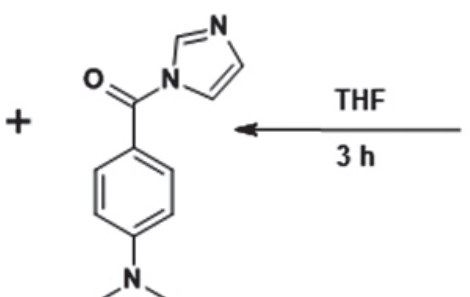

(B)<smiles>CN(C)C1=C[CH+]C(C(=O)O)=C=C1</smiles><smiles>CN(O)c1ccc(C(=O)OCC(O)(O)CO)cc1</smiles>
$0.5^{\circ} \mathrm{C}$

(C)

(D)

$\underset{\text { Boric acid, Diglyme, } \mathrm{H}_{2} \mathrm{O}}{\longrightarrow}$<smiles>NN[AlH2]</smiles><smiles>O=C(O)c1ccc(N=Nc2nc(N(C(=O)O)C(=O)O)ccc2C(=O)OCC(O)CO)cc1</smiles><smiles>Nc1ccc([N+](=O)[O-])cc1</smiles>
$\mathrm{HCl}, \mathrm{NaNO}_{2}$ $0.5{ }^{\circ} \mathrm{C}$<smiles>N#[N+]c1ccc([N+](=O)[O-])cc1</smiles>
$0.5^{\circ} \mathrm{C}$

(F)<smiles>CO[N+](=O)c1ncc(N=Nc2nc(C(=O)OCC(O)CO)ccc2N([Tl])[Tl])nn1</smiles> 


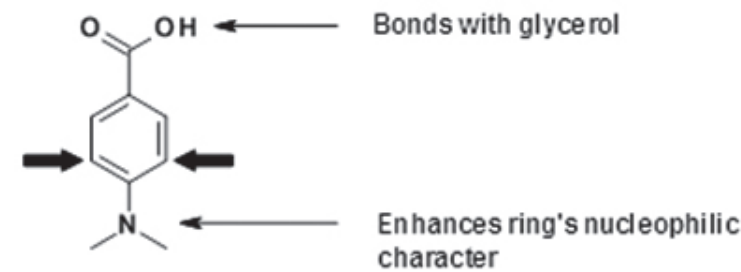

Figure 3.- 4- (dimethylamino) benzoic acid.

For esterification, $\mathrm{COOH}$ of 4-(dimethylamino)benzoic acid was reacted with 1,1 '-carbonyldimidazole ${ }^{12,13}$ that incorporated imidazole leaving group in the carboxylic acid group to form B. A was then added to the reaction media along with $\mathrm{N}\left(\mathrm{CH}_{3}\right)_{3}$, base to obtain the product $\mathbf{C}$. Obtained spectral data matched up completely with that reported in literature ${ }^{14}$.

The protected $\mathrm{OH}$ sites of $\mathbf{C}$ are then deprotected in acidic media. This step gave coupling component D (Couplar II) with open $\mathrm{OH}$ sites formed separately, prior to chromophore formation. D was subsequently azo coupled with diazotized 4-nitroaniline to afford the targeted compound $\mathbf{E}$. Care was taken in the temperature control of deprotection step as stronger acidic condition at high temperature might result in hydrolysis of ester bond between glycerol moiety and benzoic acid.

Deprotection was also attempted to be infused in the diazotization step. In a separate reaction, 4-aminoacetophenone was diazotized with sodium nitrite in acidic conditions and the resulting diazonium compound was reacted with intermediate $\mathbf{C}$ to obtain the target compound $\mathbf{F}$. Acidic conditions of azo coupling reaction were found to be capable of hydrolyzing the ketal. This approach resulted into $\mathbf{F}$. Direct azo coupling of $\mathbf{C}$ cuts down the deprotection step, but it doesn't give a 1,2-diol functional coupling component intermediate such as $\mathbf{D}$, prior to chromophore formation. Thus the opportunity to further manipulate the coupling components structure prior to chromophore formation ceases to exist. Product mass of $\mathbf{F}$ was found to contain both protected and deprotected forms of $\mathbf{F}$ and required further chromatographic purification.

Spectral properties of both $\mathbf{E}$ and $\mathbf{F}$ were quite similar. IR spectra of $\mathbf{F}$, gives back the $\mathrm{O}-\mathrm{H}$ absorption band at $3442.6 \mathrm{~cm}^{-1}$ even though there was no prior deprotection step carried out. Similarly, the emergence of a new absorption band at $1519.8 \mathrm{~cm}^{-1}$ indicated azo bond formation. Usually, a new peak at 1450 $1600 \mathrm{~cm}^{-1}$ after azo coupling reactions, is a sign for $\mathrm{N}=\mathrm{N}$ formation ${ }^{15}$. The $\mathrm{C}=\mathrm{O}$ band also showed dual peaks due to two different types of $\mathrm{C}=\mathrm{O}$ present in the molecule. In IR spectra of $\mathbf{E}$, a new peak emerged at $1514.0 \mathrm{~cm}^{-1}$ showing formation of $\mathrm{N}=\mathrm{N}$ bond.

In ${ }^{1} \mathrm{H}-\mathrm{NMR}$ of $\mathbf{F}$, a singlet of three protons appeared at $\delta 2.59 \mathrm{ppm}$, indicating the $\mathrm{CH}_{3}(\alpha$ to the $\mathrm{C}=\mathrm{O}$ ) of acetophenone. In spectra of both $\mathbf{E}$ and $\mathbf{F}$, two doublets of two protons each appeared at $\delta 7.93$ and $7.54 \mathrm{ppm}$ for $\mathbf{E}$ and at 8.01 and 7.97 ppm for $\mathbf{F}$. These two signals represent the four aromatic protons on the second aromatic ring (diazonium ring) of azo chromophore. The downfield signals at $\delta 8.01 \mathrm{ppm}$ in $\mathbf{F}$ and $8.97 \mathrm{ppm}$ in $\mathbf{E}$ were that of two protons on $\mathrm{C}_{15}$ and $\mathrm{C}_{17}$, ortho to the ketone and nitro substituents respectively. Three signals appeared for three aromatic protons on the aromatic ring of coupling component, now part of azo chromophore. Proton on $\mathrm{C}_{10}$, ortho to both $\mathrm{N}=\mathrm{N}$ and $\mathrm{C}=\mathrm{O}$ of ester, appeared at $\delta 8.02 \mathrm{ppm}$ in $\mathbf{F}$ and at $8.01 \mathrm{ppm}$ in spectra for $\mathbf{E}$. This signal in both dyes, is the most downfield in all of the spectra. Other two protons on $\mathrm{C}_{6}$ and $\mathrm{C}_{7}$ i.e. ortho and meta to $\mathrm{C}=\mathrm{O}$ of ester showed up at $\delta 7.69$ and $6.86 \mathrm{ppm}$ in $\mathbf{E}$ and at 7.89 and $7.49 \mathrm{ppm}$ in $\mathbf{F}$. Glycerol's alkyl skeleton of three carbon atoms is retained in intermediates $\mathbf{A}, \mathbf{C}, \mathbf{D}$ and subsequently in target compounds $\mathbf{E}$ and $\mathbf{F}$. Two distereotopic protons on $\mathrm{C}_{1}$, two on $\mathrm{C}_{3}$ and the lone proton on $\mathrm{C}_{2}$, gave five multiplets in the range of $\delta 3.86-4.43 \mathrm{ppm}$ in $\mathbf{E}$ and at $\delta 3.86-4.44 \mathrm{ppm}$ in $\mathbf{F}$. The splitting pattern was same as that of aliphatic protons of $\mathbf{A}, \mathbf{C}$ and $\mathbf{D}$. Singlet of six equivalent protons on $\mathrm{C}_{11}$ and $\mathrm{C}_{12}$ showed up at $\delta 3.03$ and 3.05 for $\mathbf{E}$ and $\mathbf{F}$ respectively. Mass spectra (CI-MS) of both $\mathbf{E}$ and $\mathbf{F}$ showed a common peak of $266.1 \mathrm{~m} / \mathrm{z}$ which is attributed to loss of diazonium ring with its para position substituent.

We used 4-nitoaniline and 4-aminoacetophenone for azo coupling with coupling components $\mathbf{D}$ and $\mathbf{C}$ respectively, but other aniline derivatives can also be employed. This flexibility provides the opportunity to manipulate the chromatic and many other properties of the intended molecule. Differen substituent groups on aniline can result in different shades. Selection of 4-(dimethylamino)benzoic acid as activated arene with $\mathrm{N}\left(\mathrm{CH}_{3}\right)_{2}$ at para position pays off in the azo coupling reaction, as it directs the incoming electrophile towards its ortho position. The other substituent on the rings of $\mathbf{C}$ and $\mathbf{D}$ i.e. $\mathrm{C}=\mathrm{O}$ of ester, being a deactivating group, directs at its meta position, which happens to be the ortho of $\mathrm{N}\left(\mathrm{CH}_{3}\right)_{2}$. Hence, both substituents are directing at the same position as demonstrated by block arrows in Figure 3.

Since this research is focused on application of these compounds in the textile wet processing industry, the water solubility of these compounds is of high importance. Because of high alkyl content in targeted molecule and resultant hydrophobic nature, it would be difficult to apply on the substrate from an aqueous bath. Utilization of a dispersing agent enables the application onto the substrates from aqueous baths. This mode of application puts this molecule in the category of disperse dyes ${ }^{16,17}$

\section{CONCLUSION}

We designed novel 1,2-diol containing azo dyes through multistep synthesis scheme. Presence of diol on the edge of the molecule gives rise to stronger interaction with polar sites of the polymeric textile substrate through hydrogen bonding. Because of such interaction, dye molecules showed good to excellent fastness properties. Series of molecules with different chromatic properties can be synthesized on the same pattern.

\section{ACKNOWLEDGMENTS}

We thank Archroma Pakistan ltd. for their support in this project. We are also thankful to Dean Faculty of Science of University of Karachi, Pakistan for all the assistance in this research work.

\section{REFERENCES}

1. K. Suganuma, Text. Res. J., 49, 536-539 (1979)

2. S. Ugbolue, Polyolefin Fibers, Woodhead Pub., Cambridge, 2009; pp. 376

3. H. S. Bhatti, S. Seshadri, Color. Technol., 120, 151-155 (2004).

4. A. Z. Sayed, M. S. Aboul-Fetouh, H. S. Nassar, J. Mol. Struct., 1010, 146-151 (2012).

5. T. A. Khattab, K. M. Haggag, M. H. Elnagdi, A. A. Abdelrahman, S. A Aly, Z. Anorg. Allg. Chem., 642, 766-772 (2016)

6. F. Karci, F. Karci, A. Demircali, M. Yamac, J. Mol. Liq., 187, 302-308 (2013).

7. R. Christie, Color Chemistry, $2^{\text {nd }}$ ed., Royal Society of Chemistry, London, 2014; pp.186.

8. W.H. Brown, Organic Chemistry, $6^{\text {th }}$ ed., Brooks/Cole, Cengage Learning, Belmont, 2012; pp. 953.

9. A. Bafana, S.S. Devi, T. Chakrabarti, Environ. Rev.,19, 350-371 (2011).

10. L. Chrysler, Methods of Test for Color Fastness of Textiles and Leather, $7^{\text {th }}$ ed., Bradford, London, 1990; pp. 89-94.

11. N. Suriyaprapadilok, B. Kitiyanan, Energy Procedia, 9, 63-69, (2011)

12. S. Verma, R. Ghorpade, A. Pratap, M. Kaushik, Tetrahedron Lett., 53, 2373-2376, (2012)

13. D. Klemm, T. Heinze, Polysaccharides II, Springer, Berlin, 2006; pp. 238

14. C. Carola, F. Pfluecker, H. Buchholz, H. Driller, H. Neunhoeffer, E. Blyumin, US20080038213 A1, (2008)

15. C. Yuen, Res. J. Text. Apparel, 9, 26-38, (2005).

16. T. Shah, R. Shiny, R. Dixit, B. Dixit, J. Saudi Chem. Soc.,18, 985-992, (2014).

17. K. Singh, S. Singh, A. Mahajan, J. Taylor, Color. Technol., 119, 198-204, (2003). 